FIU Law Review

Volume 1

Number 1 Inaugural Issue

Article 9

Spring 2006

\title{
The Constitution and Human Rights: The International Legal Constructionist Approach to Ensuring the Protection of Human Rights
}

Francisco Forrest Martin

Follow this and additional works at: https://ecollections.law.fiu.edu/lawreview

Part of the Other Law Commons

Online ISSN: 2643-7759

Recommended Citation

Francisco F. Martin, The Constitution and Human Rights: The International Legal Constructionist Approach to Ensuring the Protection of Human Rights, 1 FIU L. Rev. 71 (2006).

DOI: https://dx.doi.org/10.25148/lawrev.1.1.9

This Symposium is brought to you for free and open access by eCollections. It has been accepted for inclusion in FIU Law Review by an authorized editor of eCollections. For more information, please contact lisdavis@fiu.edu. 


\title{
The Constitution and Human Rights: The International Legal Constructionist Approach to Ensuring the Protection of Human Rights
}

\author{
Francisco Forrest Martin ${ }^{\dagger}$
}

\section{INTRODUCTION}

The continuing irony for many U.S. human rights advocates is our nation's claim that the United States is the most free country in the world due in large measure to our Constitution while at the same time our government goes about undermining and violating human rights at home and abroad. ${ }^{1}$ Particularly troubling is the U.S. government's failure to live up to its international human rights legal obligations. If we are to have, as John Adams said, "a government of laws, not men," then our government should be acting in conformity with its human rights legal obligations both national and international. $^{2}$

Two major developments in constitutional interpretation have contributed to this frustration of achieving the full human rights protection provided by international law. ${ }^{3}$ First, the Supreme Court in the late nineteenth century repeatedly held in a number of cases upholding anti-immigrant and anti-Native-American federal legislation that Congress could void a treaty by enacting a new law. ${ }^{4}$ Second, federal courts have declared that some

$\dagger \quad$ President, Rights International, The Center for International Human Rights Law, Inc.

1 See, e.g., AMNESTY INTERNATIONAL REPORT 2005: THE STATE OF THE WORLD'S HUMAN RIGHTS (2005); THE HUMAN RIGHTS WATCH WORLD REPORT 2005 (2005).

2 VII Novanglus [John Adams], A History of the Dispute with America, From Its Origin, in 1754 to the Present Time (1774), in The Revolutionary Writings of John AdAms 226 (C. Bradley Thompson ed., 2001).

3 This Article will not address how constitutional interpretation has failed to incorporate international human rights legal standards in various substantive areas, such as the death penalty, privacy, or due process. Such a treatment already has been provided elsewhere. See, e.g., FrANCISCO ForREST Martin, Challenging Human Rights Violations: Using InTERnATIONAL LaW IN U.S. Courts (2001) [hereinafter Martin, Challenging Human Rights Violations]. This Article will address more formal issues challenging the incorporation of international human rights law in U.S. constitutional law.

4 See, e.g., The Cherokee Tobacco, 78 U.S. (11 Wall.) 616 (1870) (breaking treaty with Cherokee nation by charging tax on tobacco); Head Money Cases, 112 U.S. 580 (1884) (breaking friendship treaties by charging head tax on entering aliens); Chae Chan Ping v. United States, 130 U.S. 581 (1889) (breaking treaty with China by excluding Chinese immigrants); Thomas v. Gay, 169 U.S. 264 (1898) 
treaty norms are non-self-executing. ${ }^{5}$ Such norms require implementing legislation for the courts to enforce them.

This Essay will argue that these two obstacles can be overcome by embracing a somewhat new paradigm of constitutional interpretation-one that recognizes that the Constitution is a treaty that must be construed in conformity with the United States' international legal obligations per the conventional law of nations. ${ }^{6}$ This interpretive approach is called "International Legal Constructionism" ("ILC"), which has been presented in an earlier article. ${ }^{7}$ ILC is not really new. The Founding Fathers and Framers effectively ascribed to it. However, it appears to have become lost over the last 150 years in part due to the nationalist victory in the Civil War and the United States' growing hegemony in international relations. Nevertheless, if constitutionalists are serious about ensuring human rights protections, we need to return to this original paradigm of constitutional understandingespecially in the new globalized world order.

\section{THE LAST-IN-TIME RULE}

The "Last-in-Time" Rule states that a federal statute can supercede a treaty obligation if the statute was enacted after the ratification of the treaty. The Rule also states that a federal statute is trumped by a later ratified treaty. Both statements of the Rule are premised on the claim that federal statutes and treaties have equal legal authority under the Constitution. The Rule continues to vex human rights advocates, as evidenced by the Supreme Court's 1998 ruling in Breard v. Greene ${ }^{8}$ in which the Court denied petitioner's request for a writ of habeas corpus in part on the basis that the

(breaking treaty with Cherokee nation by denying self-government); Stephens v. Cherokee Nation, 174 U.S. 445 (1899) (breaking treaty with Cherokee nation by taking land).

5 See, e.g., Igartua de la Rosa v. United States, 32 F.3d 8, 10 n.1 (1st Cir. 1994) (declaring rights provisions in the International Covenant on Civil and Political Rights non-self-executing); Ralk v. Lincoln Country, Georgia, 81 F. Supp. 2d 1372, 1380 (S.D. Ga. 2000) (same); Heinrich v. Sweet, 49 F. Supp. 2d 27, 43 (D. Mass. 1999) (same); White v. Paulsen, 997 F. Supp. 1380, 1386 (E.D. Wash. 1998) (same); In the Matter of the Extradition of Cheung, 968 F. Supp. 791, 803 n.17 (D. Conn. 1997) (same).

6 The conventional law of nations is the international law governing the interpretation of treaties. Much of this international law is codified in the Vienna Convention on the Law of Treaties, May 23 , 1969, 1155 U.N.T.S. 331 (entered into force Jan. 27, 1980) [hereinafter Vienna Convention] and the Vienna Convention on the Law of Treaties Between States and International Organizations or Between International Organizations, Mar. 21, 1986, U.N. Doc. A/CONF.129/15, 25 I.L.M. 543 [hereinafter Vienna Convention-SIO].

7 For a fuller discussion of International Legal Constructionism, see Francisco Forrest Martin, Our Constitution as Federal Treaty: A New Theory of United States Constitutional Construction Based on an Originalist Understanding for Addressing a New World, 31 HASTINGS CONST. L. QUART. 259-354 (2004) [hereinafter, Martin, Our Constitution as Federal Treaty].

8523 U.S. 371 (1998). In late 2004, the U.S. Supreme Court agreed to re-examine the United States' obligations under the Vienna Convention on Consular Relations in another case. See Medellin v. Dretke, No. 04-5928 (rev. grant.). However, the Court later dismissed the writ of certiorari in this case as improvidently granted. 125 S. Ct. 2055 (2005) (per curiam) (slip opinion). 
Antiterrorism and Effective Death Penalty Act (AEDPA) ${ }^{9}$ superceded the earlier ratified the Vienna Convention on Consular Relations that guaranteed foreign nationals the right to consular assistance when they are arrested. ${ }^{10}$

I submit that the Last-in-Time Rule is an unconstitutional and immoral judge-made rule on a number of grounds. First, the Rule's application in many cases can violate the constitutional separation of powers principle by nullifying the President's authority to make treaties that have the status of federal law. ${ }^{11}$ Although Congress can make federal statutory law without the President's approval if the legislation acquires two-thirds votes in each House, ${ }^{12}$ it is different with treaties. The President's approval is necessary to a treaty becoming part of the "supreme Law of the Land." The House of Representative's approval is not required for a treaty to be supreme law. Therefore, the House of Representatives has no role in either making or unmaking treaties. Allowing a federal statute to supercede an earlier ratified treaty would nullify the President's constitutional co-authority with the Senate to make federal law, thereby violating the separation of powers principle.

The only two arguable applications of the Last-in-Time Rule that would not run afoul of the separation of powers principles are when (i) both the President and two-thirds of the Senate approve legislation that conflicts with an earlier ratified treaty, and (ii) the President and Senate make a treaty that conflicts with earlier legislation enacted over a President's veto.

However, even these last case scenarios still would create a conflict with the text of the Constitution, thereby raising a second problem with the Last-in-Time Rule. The text of the Supremacy Clause indicates that treaties have greater authority than federal statutory law. Treaties are made under the authority of the United States, ${ }^{13}$ and such authority precedes the establishment of our constitutional government as the text of the Supremacy Clause indicates by recognizing the continuing supreme legal authority of treaties made under the Articles of Confederation. The United States legally could dissolve the Constitution (as it did earlier with the Articles of Con-

\footnotetext{
928 U.S.C.A. $\$ \S 2254(a)-(e)(2)$ (Supp. 1998).

10 Apr. 24, 1963, [1970] 21 U.S.T. 77, T.I.A.S. No. 6820.

11 See U.S. Const. art. II § 2, cl. 2 (Sept. 17, 1787; entered into force June 21, 1788) (President "shall have Power, by and with the Advice and Consent of the Senate to make Treaties, provided two thirds of the Senators present concur”) [hereinafter U.S. CONST.]; U.S. CONST. art. VI, § 2 ("[A]11 Treaties made, or which shall be made, under the Authority of the United States, shall be the supreme Law of the Land; and the Judges in every State shall be bound thereby, any Thing in the Constitution or Laws of any State to the Contrary notwithstanding.").

12 U.S. CONST. art. I, § 7, cl. 2.

13 U.S. CONST. art. VI, § 2.
} 
federation - but this time by unanimous state consent $)^{14}$ and establish a new form of government. If it did so, treaties would continue to bind the United States (as they did under the Constitution).

On the other hand, federal statutes are only made in pursuance of the Constitution. $^{15}$ The authority of federal statutes relies solely upon the Constitution. If the United States dissolved the Constitution and established a new constitution, federal statutes enacted in pursuance of the old Constitution would no longer be valid (unless the new constitution provided so).

Most importantly, if Congress enacts a federal statute on subjectmatter that exceeds the powers explicitly delegated to the political branches ${ }^{16}$ or enacts a federal statute that violates substantive provisions of the Constitution, ${ }^{17}$ such federal statutes are constitutionally invalid. On the other hand, treaties constitutionally can govern matters not explicitly addressed in the Constitution because there is no subject-matter limitation on the treaty-making authority of the President and Senate in the Constitution. For example, Congress could not enact a law that violates a treaty guaranteeing the right to explore Mars for scientific purposes because Congress has no apparent enumerated power to prohibit scientific exploration in outer space. In such a case, the treaty has greater constitutional authority than a federal statute.

The only arguable constitutional limitation on the treaty power, as the U.S. Supreme Court in Reid v. Covert held, ${ }^{18}$ is that treaties cannot violate the Constitution. ${ }^{19}$ Indeed, this holding is consistent with international law. The Vienna Convention on the Law of Treaties allows a state to nullify a treaty if the treaty manifestly violates a fundamental rule of its internal law, such as its constitution. ${ }^{20}$ Furthermore, in the context of international hu-

14 Non-unanimity was legally sufficient for ratifying the Constitution because state violations of the Articles and the failure of the states to use federal courts for resolving allegations of state Articles violations enabled the United States to adopt a nine-state rule for ratifying the Constitution. See Martin, Our Constitution as Federal Treaty, supra note 7 at 283-91. Furthermore, a constitutional amendment probably would be insufficient because all states are parties to the Constitution, and the ratification of only three-fourths of the states is required for an amendment to go into force. U.S. CONST. art. V. Therefore, unanimous state consent would be required in order to dissolve the Constitution.

15 U.S. CONST. art. VI, § 2 ("This Constitution, and the Law of the United States which shall be made in Pursuance thereof; . . . shall be the supreme Law of the Land").

16 See, e.g., Clinton v. City of New York, 524 U.S. 417 (1998) (federal statute allowing line-item veto held unconstitutional because veto exceeds political branches' constitutional powers).

17 See, e.g., Marbury v. Madison, 5 U.S. (1 Cranch.) 137 (1803) (federal statute in violation of Constitution is void).

18 Reid v. Covert, 354 U.S. 1, 15-19 (1957).

19 For example, a treaty governing space exploration could not violate the Constitution because the Constitution does not address space exploration-unless the treaty violated, e.g., the Fifth Amendment's Due Process Clause by requiring summary executions of astronauts who attempt to pirate the space vessel. Interestingly enough, however, no U.S. court has ever found any treaty unconstitutional.

20 See Vienna Convention, art. 46 (1) ("A State may not invoke the fact that its consent to be bound by a treaty has been expressed in violation of a provision of its internal law regarding competence 
man rights legal protections, the Vienna Convention also says that treaties cannot violate human rights and humanitarian law protections. ${ }^{21}$

Therefore, if treaties have greater constitutional authority then federal statutes, then the Last-in-Time Rule's assumption that federal statutes have equal constitutional authority with treaties, is invalid.

A third problem with the Last-in-Time Rules is that early U.S. Supreme Court precedent also indicated that treaties could not be violated. In The Antelope, the Court in 1812 noted that treaties could not be violated.

In almost every instance, the treaties between civilized nations contain a stipulation to this effect in favor of vessels driven in by stress of weather or other urgent necessity. In such cases the sovereign is bound by compact to authorize foreign vessels to enter his ports. The treaty binds him to allow vessels in distress to find refuge and asylum in his ports, and this is a license which he is not at liberty to retract.

Fifty-two years later, the Supreme Court failed to address this earlier dictum and reversed itself by fabricating the Last-in-Time Rule. In doing so, the Court legitimized a continuing legacy of racial discrimination against Native-Americans and aliens ${ }^{23}$ that later culminated in the Court's Plessy v. Ferguson decision against African-Americans. ${ }^{24}$ For example, in Chae Chan Ping v. United States, the Supreme Court in allowing Congress to break a U.S.-China treaty guaranteeing Chinese immigration to the United States stated that "the presence of Chinese laborers had a baneful effect upon the material interests of the state, and upon public morals; that their immigration was in numbers approaching the character of an Oriental invasion, and was a menace to our civilization." 25 Seven years later, the Court would extend its racism to African-Americas in Plessy v. Ferguson by facetiously asserting that "[1]aws permitting, and even requiring, [the separation of Whites and Negroes], in places where they are liable to be brought into contact, do not necessarily imply the inferiority of either race to the other ....,26

to conclude treaties as invalidating its consent unless that violation was manifest and concerned a rule of its internal law of fundamental importance."); Vienna Convention-SIO, art. 46.

21 Vienna Convention, art. 60 (5) (breach of human rights or humanitarian treaty by state-party does not entitle other state-party to terminate or suspend operation of treaty).

22 See The Antelope, 11 U.S. (7 Cranch) 116, 141 (1812) (emphasis provided).

23 See, e.g., The Cherokee Tobacco, 78 U.S. (11 Wall.) 616 (1870) (breaking treaty with Cherokee nation by charging tax on tobacco); Head Money Cases, 112 U.S. 580 (1884) (breaking friendship treaties by charging head tax on entering aliens); Chae Chan Ping v. United States, 130 U.S. 581 (1889) (breaking treaty with China by excluding Chinese immigrants); Thomas v. Gay, 169 U.S. 264 (1898) (breaking treaty with Cherokee nation by denying self-government); Stephens v. Cherokee Nation, 174 U.S. 445 (1899) (breaking treaty with Cherokee nation by taking land).

24163 U.S. 537 (1896).

25130 U.S. $581,595$.

26163 U.S. 537, 544. 
Indeed, this discrimination against Native Americans and aliens runs afoul of the constitutional guarantee of equal protection of the laws. Although the Fourteenth Amendment's equal protection guarantee only applies, strictly speaking, to the states, ${ }^{27}$ the Supreme Court later has interpreted the Fifth Amendment's substantive due process protections to include the right to equal protection of the laws-especially in regard to aliens. $^{28}$ Such an interpretation of the Fifth Amendment also is consonant with earlier Supreme Court precedent that held that the United States' treaty obligations should be construed liberally in order to avoid conflicts with our treaty-partners whose nationals could otherwise be the subject of harmful alienage discrimination. ${ }^{29}$ Accordingly, any federal statute that discriminates against aliens by voiding previous treaty obligations protecting them should be subjected to strict scrutiny at the very least. ${ }^{30}$

A fourth problem with the Last-in-Time Rule is that unnecessarily overreaches to flatly assert that the Congress constitutionally could void treaties anytime that it wished by later enacting legislation. International law itself allows states to void, suspend, or withdraw from treaty obligations on a number of grounds. For example, material breach by a treaty partner and fraud are lawful grounds for abrogating a treaty; a fundamental change of circumstances is a lawful ground for withdrawing from a treaty; and treaty suspension or withdrawal may be allowed by the treaty itself. ${ }^{31}$

Although states have inherent sovereignty (including the right to determine who can and cannot immigrate ${ }^{32}$ as was the case with the Chinese Exclusion Cases ${ }^{33}$ ), this sovereignty is limited by the sovereign's own capacity to impose self-limits by entering into treaties or acceding to emerging customary international legal obligations. Sovereignty is not a trump card for getting out of one's legal obligations when s/he has the predilection to do so.

27 See U.S. CONST. amend. XIV, § 1 ("No State shall ... deny to any person within its jurisdiction the equal protection of the laws.").

28 See Hampton v. Wong, 426 U.S. 88 (1976) (federal alienage discrimination violative of 5th Amendment guarantee prohibiting denial of liberty without due process of law).

29 See Geofroy v. Riggs, 133 U.S. 258, 271 (1890) ("It is a general principle of construction with respect to treaties that they shall be liberally construed, so as to carry out the apparent intention of the parties to secure equality and reciprocity between them.").

$30 C f$. Bernal v. Fainter, 467 U.S. 216 (1984) (strict scrutiny test applied to state discrimination on basis of alienage).

31 See, e.g., EMmerich de VATtel, 2 The LaW of Nations or Principles of the LaW of NATURE APPliEd TO THE CONDUCT AND AFFAIRS OF NATIONS AND SOVEREIGN § 202 (1758) (treaty breach) [hereinafter, VATTEL, LAW OF NATIONS]; id. at $§ 296$ (change of circumstances); Vienna Convention, arts. 54 (termination or withdrawal allowed by treaty), 60 (breach), and 62 (fundamental change of circumstances).

32 Harisiades v. Shaughnessy, 342 U.S. 580 (1952).

33 Chae Chan Ping, 130 U.S. 581, 595. 
The fifth problem with the Last-in-Time Rule is its conflict with the Framers' claim that treaties were supreme over federal statutory law. For example, Alexander Hamilton stated that it was "understood by all" during the Constitutional Convention that the Constitution's treaty power was "competent to ... controul and bind the legislative power of Congress" and that "no objection was made to the idea of its controuling future exercises of the legislative power." ${ }^{34}$ John Jay gave one reason why federal statutes could not supercede the United States' treaty obligations:

They who make laws, may, without doubt, amend or repeal them; and it will not be disputed that they who make treaties may alter or cancel them; but still, let us not forget, that treaties are made, not by only one of the contracting parties, but by both; and consequently, that as the consent of both was essential to their formation at first, so must it ever afterwards be to alter or cancel them. The proposed Constitution, therefore, has not in the least extended the obligation of treaties. They are just as binding, and just as far beyond the lawful reach of legislative acts now, as they will be at any future period, or under any form of government. ${ }^{35}$

William Davie went further and stated that treaties were supreme over federal statutes:

[A]lthough treaties are mere conventional acts between the contracting parties, yet, by the law of nations, they are the supreme law of the land to their respective citizens or subjects. All civilized nations have concurred in considering them as paramount to an ordinary act of legislation. $^{36}$

A sixth reason for rejecting the Last-in-Time Rule is that when the U.S. government violates its treaty obligations with its treaty partners, these states-parties under the conventional law of nations can lawfully abrogate their international legal obligations with the American people (with the exception of humanitarian or human rights norms). Such action by the U.S. government would violate the social contract established by the American people, and we should recall that violations of international law by the British Parliament constituted one of the justifications for breaking our ties with Great Britain mentioned in the Declaration of Independence. ${ }^{37}$

\footnotetext{
34 Alexander Hamilton, The Defence No. 38 (1795), in 20 THE PAPERS OF ALEXANDER HAMILTON 22, 25 n.* (Harold C. Syrett ed., 1974).

35 THE FEDERALIST No. 64 (Jay John) at II 12 (1788).

364 The Debates in the Several State Conventions on the adoption of the Federal CONSTITUTION 119 (Jonathan Elliot ed., 1968) [hereinafter ELLIOT's DEBATES].

37 See DECLARATION OF INDEPENDENCE para. 3 (dissolution of social contract with Great Britain justified on bases of Britain's "cutting off our Trade with all parts of the world. ... [and the] . . plun-
} 
The seventh reason is that the need for the Last-in-Time Rule is premised on a false notion of Congressional Supremacy. The Constitution does not explicitly incorporate the Last-in-Time Rule; therefore, one must attempt to provide a justification of it on the basis of some general constitutional principle extrapolated from the text of the Constitution. The obvious choice is a principle of Congressional Supremacy in lawmaking extrapolated from Article I that states "[a]ll legislative Powers . . . shall be vested in [the] Congress ...." The notion of Congressional Supremacy in lawmaking appears to be derived from the British principle of Parliamentary Supremacy, and the British Parliamentary Supremacy Principle requires the use of a last-in-time rule that always allows Parliament to reverse its own supreme laws.

However, a comparison of purported Congressional Supremacy with Parliamentary Supremacy highlights how the Last-in-Time Rule's application to treaties is based on the false premise of Congressional Supremacy. Insofar as the American Last-in-Time Rule is premised on the basis of its need to ensure Congressional Supremacy, the premise for this justification is false. The United States rejected the British constitutional principle of Parliamentary Supremacy by declaring its independence from Great Britain and forming governments under the Articles of Confederation and the Constitution that did not make their respective Congresses supreme. The American Last-in-Time Rule itself makes Congressional supremacy impossible by allowing the President (with the consent of the Senate) to make a treaty that supercedes an earlier Congressionally enacted federal statute. If there is no valid constitutional principle upon which to justify the Last-inTime Rule, the Rule is the mere product of judges exercising a political predilection in favor of Congress.

der[ing of] our seas.”). The law of nations guarantees freedom of trade and the seas. See, e.g., HugO GROTIUS, THE FREEDOM OF THE SEAS ch. 12 (1609).

38 Furthermore, the American Last-in-Time Rule is a corruption of the British last-in-time rule because treaties under British constitutional law never have domestic legal effect (without acts of Parliament giving them such effect). This is not the case with U.S. constitutional law in which treaties often do have domestic legal effect without the need for implementing legislation. See infra discussion in Part 2. Therefore, the British last-in-time rule is inapplicable to British treaties because they do not have equal legal status with acts of Parliament. The British last-in-time rule only applies to acts of Parliament, whereas the American Last-in-Time Rule applies to both statutes and treaties.

On the other hand, one may argue that the American Last-in-Time Rule is just an adaptation-not a corrupted version —of the British rule to the peculiar American constitutional scheme purportedly making treaties equal to statutes, which British constitutional law does not. If Parliament in the future were to enact legislation stating that all treaties have equal status to acts of Parliament and subsequently enacts a statute violating one of these treaties, this statute would be constitutional under the British lastin-time rule only because of the Parliamentary Supremacy Principle. Hence, a last-in-time rule would be applicable. However, if Congress were to enact a statute inconsistent with an earlier ratified U.S. treaty, the application of a last-in-time rule to supercede the treaty could not be based on a rule of Congressional supremacy because the President still later could make a treaty superseding this statute. Again, there is no Congressional supremacy upon which to base the Last-in-Time Rule's application to treaties. 
Most importantly, the eighth and final reason for rejecting the Last-inTime Rule is that fundamental morality dictates that we keep our promises. We teach our children that they should keep their promises unless the promise itself is wrong or circumstances have changed that would lead to greater harms. It is the same with treaties in which our elected representatives enter into agreements with other peoples (i.e., nations) on our behalf and with our constructive consent. This is a lesson that the Supreme Court never learned.

Although we have discussed textual, historical, jurisprudential, political, and moral reasons for rejecting the Last-in-Time Rule, there is a more direct route for such a rejection by means of construing the Constitution in conformity with the United States' international legal obligations. Per the ILC approach, Congress' constitutional authority under Article I, $\S 8$ to enact legislation must be construed in conformity with international law, and international law prohibits states from failing to perform their treaty obligations. $^{39}$ If such an approach is taken, the Last-in-Time Rule's application to earlier ratified treaties is no longer constitutional. ${ }^{40}$

39 Vienna Convention, art. 27 ("A party may not invoke the provisions of its internal law as justification for its failure to perform a treaty. ...”).

40 Also, recent federal court practice seems to suggest that federal statutes and executive orders always trump customary international law regardless of when it emerged. See, e.g., Galo-Garcia v. Immigration \& Naturalization Serv., 86 F.3d 916 (9th Cir. 1996) (federal statute supercedes customary international law); Comm. of U.S. Citizens Living in Nicaragua v. Reagan, 859 F.2d 929 (D.C. Cir. 1988) (federal statute supercedes customary international law); United States v. Merkt, 794 F.2d 950 (5th Cir. 1986) (federal statute supercedes customary international law); Garcia-Mir v. Meese, 788 F.2d 1446 (11th Cir. 1986) (federal statutes and executive orders supercede customary international law); United States v. Howard-Arias, 679 F.2d 363 (4th Cir. 1982) (federal statute supercedes customary international law); Tag v. Rogers, 267 F.2d 664 (D.C. Cir. 1959) (federal statute supercedes customary international law).

However, this recent, judge-made rule is also fraught with insurmountable problems, such as its basis on a paraphrasing of dicta in the U.S. Supreme Court's The Paquete Habana, 175 U.S. 677, 700 (1900) (dictum) ("where there is no treaty, and no controlling executive or legislative act or judicial decision, resort must be had to the customs and usages of civilized nations") that is overreaching. For example, some federal courts have overreached the dictum's meaning by adding the word "only," as in "only "where there is not treaty, and not controlling executive or legislative act or judicial decision, resort must be had to the customs and usages of civilized nations." In the Matter of the Extradition of Cheung, 968 F. Supp. 791, 803 n. 17 (D. Conn. 1997); see also Dimon-Sainz v. United States, No. $97-$ 3117-RDR, 1999 U.S. Dist. LEXIS 18582 (D. Kan. 1999) (same); Tag v. Rogers, 267 F.2d 664 (D.C. Cir. 1959) (same).

The application of the Last-in-Time Rule to customary international law also fails to recognize earlier conflicting case law and authorities. See, e.g., Macintosh v. United States, 283 U.S. 605, 622 (1931) (dictum) (Congress under war powers authority cannot violate international law); see also Jordan Paust, Rediscovering the Relationship Between Congressional Power and International Law: Exceptions to the Last in Time Rule and the Primacy of Custom, 28 VA. J. INT'L L. 393 (1988), for additional authorities cited therein.

The Rule's application to customary international law also mischaracterizes customary international law as merely common law that can be superceded by statute. See, e.g., Louis Henkin, The Constitution and United States Sovereignty: A Century of Chinese Exclusion and Its Progeny, 100 HARv. L. Rev. 853 


\section{THE NON-SELF-EXECUTION DOCTRINE}

The second obstacle facing human rights protective constitutional construction is the Non-Self-Execution Doctrine. Mr. Chief Justice John Marshall articulated this doctrine in Foster v. Neilson ${ }^{41}$ in 1829. Marshall stated that those treaties addressed "to the political, not the judicial department" are non-self-executing. ${ }^{42}$ Therefore, "the legislature must execute the contract (i.e., the treaty) before [the treaty] can become a rule for the Court." ${ }^{43}$ Like the Last-in-Time Rule, the Non-Self-Execution Doctrine appears to have been borrowed from the British constitutional concept of Parliamentary Supremacy in that the Non-Self-Execution Doctrine ensures that legislative action by Parliament is required before treaty obligations can be performed. Otherwise, British treaties-which can be made only by the Crown-could have domestic legal effect that conflict with acts of Parliament, thereby destroying Parliamentary Supremacy.

Insofar as the United States rejected the Parliamentary Supremacy Principle and the Non-Self-Execution Doctrine prevents courts enforcing treaties without implementing legislation, this Doctrine relies on an inapplicable British constitutional principle. Article III gives the federal courts the power to decide all cases arising under treaties, ${ }^{44}$ and the Supremacy Clause requires that state judges be bound by treaties. ${ }^{45}$ In the context of human rights treaties that guarantee domestic remedies (including judicial ones),

(1987) [hereinafter Henkin, Chinese Exclusion] (disputing customary international law as being only federal common law). Evidence of much of modern customary international law is found in treaties.

The Rule's application also displaces customary international law with treaty law as a superior authority of law. If federal statutes as well as treaties have equal authority-as the Last-in-Time rule holds-then treaties trump customary international law. However, this inference generally would violate international law because one cannot make a new treaty that violates an extant customary international legal norm (unless all states that have acceded to the customary international legal norm are also states-parties to the new treaty).

And-again - the Rule's application would conflict with the original understanding of the Founders. See supra discussion. Also, the Rule's application has produced absurd results, such as indefinite detention. See, e.g., Garcia-Mir v. Meese, 788 F.2d 1446 (11th Cir. 1986) (indefinite detention). Therefore, this rule has serious constitutional infirmities; however, again, such a rule would be unconstitutional under ILC when the President's authority to issue executive orders and approve legislation, and the Congress' authority to make law is construed in conformity with United States' customary international legal obligations.

4127 U.S. (2 Pet.) 253 (1829).

$42 \quad$ Id. at 314

43 Id.

44 U.S. Const. art. III, § 2, cl. 1 ("The judicial Power shall extend to all Cases, in Law and Equity, arising under ... Treaties ....”).

45 U.S. CONST. art. VI (Supremacy Clause).

46 See, e.g., International Covenant on Civil and Political Rights, Dec. 16, 1966, art. 2, 999 U.N.T.S. 171 (entered into force Mar. 23, 1976) ("Each State Party to the present Covenant undertakes . .. [t]o ensure that any person whose rights or freedoms as herein recognized are violated shall have an effective remedy, .... [t]o ensure that any such person claiming such a remedy shall have his right 
this problem is highlighted because the Non-Self-Execution Doctrine undermines the constitutional status of treaties as law of the land, the violation of which is not remediable in the courts.

Nevertheless, since Foster v. Neilson, federal courts have declared that some treaty obligations are non-self-executing. ${ }^{47}$ Such treaty obligations require implementing legislation before the federal courts can give them domestic effect. Assuming the constitutional legitimacy of the Non-SelfExecution Doctrine, whether a particular treaty constitutionally requires implementing legislation should turn on whether its particular provisions constitutionally require implementing legislation. Certain treaty provisions may be vague requiring federal legislation to provide definition. However, in the context of human rights treaties, their substantive rights guarantees should not constitutionally require legislative definition. Like the many of human rights guarantees in the Bill of Rights, such rights are self-executing, and although Congress may enact legislation giving further definition to such international legal norms under its constitutional authority to define offences against the law of nations, ${ }^{48}$ the federal courts also have a sayindeed, for the Supreme Court, the final say-on their definition. ${ }^{49}$ Congress may be constitutionally ${ }^{50}$ required to set penalties ${ }^{51}$ for violations of a treaty's provisions ${ }^{52}$ that the treaty requires but failed to explicitly set. Other treaty provisions ${ }^{53}$ may require Congress to provide an explicit private cause of action for the violations of the provisions. ${ }^{54}$

However, if Congress fails to enact legislation giving domestic effect to the treaty's obligations, then there should be a presumption that no such legislation is constitutionally needed ${ }^{55}$ otherwise, the members of Congress

thereto determined by a competent judicial . . . authorit[y], . . . and to develop the possibilities of judicial remedy ....") [hereinafter ICCPR].

47 Federal courts also have extended the Non-Self-Execution Doctrine to include some customary international legal norms. See, e.g., Sosa v. Alvarez-Machain, 542 U.S. 692, 736 (2004) (indicating need for federal legislation to give customary international legal norms domestic effect) (dictum).

48 U.S. ConsT. art, I, $\S 8$, cl. 10.

49 Cf. Boerne v. Flores, 521 U.S. 507 (1997) (Supreme Court-not Congress-determines final meaning of federal law).

50 See U.S. ConST. art. I, $\S 8$, cl. 10 (Congress has power to punish offences against the law of nations).

51 See, e.g., "War Crimes Act of 1996," 18 U.S.C. $\$ 2441$ (a) (implementing penalty legislation for Hague and Geneva Conventions).

52 See, e.g., Geneva Convention Relative to the Protection of Civilian Persons in Time of War, Aug. 12, 1949, art. 146, 75 U.N.T.S. 287, 6 U.S.T. 3516, T.I.A.S. No. 3365 (entered into force Oct. 21, 1950) ("The High Contracting Parties undertake to enact any legislation necessary to provide effective penal provisions for persons committing, or ordering to be committed, any of the grave breaches of the prsent Convention . . ..”) [hereinafter Fourth Geneva Convention].

53 See, e.g., ICCPR, art. 2.

54 See, e.g., 28 U.S.C. $\$ 2241(\mathrm{c})(3)$ (guaranteeing writ of habeas corpus to prisoners being detained in violation of treaties).

55 RESTATEMENT (THIRD) OF FOREIGN RELATIONS LAW OF THE UNITED STATES $§ 111$, n.5 (1987) ("[I]f the Executive Branch has not requested implementing legislation and Congress has not enacted 
have failed to comply with their constitutional duty under Article VI to support the Constitution, ${ }^{56}$ specifically by failing "[t]o make all Laws which shall be necessary and proper for carrying into Execution the foregoing Powers, and all other Powers vested by this Constitution in the Government of the United States . ..."57 that includes legislation necessary for the implementation of the President's and Senate's joint treaty-making power under Article II. ${ }^{58}$

In the area of human rights, the United States ratified the ICCPR and deposited a declaration stating that the substantive human rights guarantees contained in Articles 1-27 of the ICCPR were non-self-executing. ${ }^{59}$ The United States also has deposited a similar declaration ${ }^{60}$ when it ratified the Convention Against Torture and Other Cruel, Inhuman or Degrading Treatment or Punishment ("CAT"). ${ }^{61}$ The constitutionality of such non-selfexecution declarations have been the subject of much academic discussion. $^{62}$ Furthermore, it is not even clear what exactly the Bush Administration and the Senate meant by "non-self-executing" in relation to the ICCPR and $C A T{ }^{63}$ Some federal and state courts often have provided the most sweeping definition to the term by holding that the declaration effectively guts the treaty by denying any enforcement of the treaty's human rights by the courts. ${ }^{64}$ The treaty's human rights obligations do not in any way bind

such legislation, there is a strong presumption that the treaty has been considered self-executing by the political branches, and should be considered self-executing by the courts.").

56 U.S. ConST. art. VI, cl. 3 ("The Senators and Representatives before mentioned . . . and all executive and judicial Officers . . . of the United States . . . shall be bound by Oath or Affirmation, to support this Constitution ....").

57 U.S. CONST. art. I, $\S 8$, cl. 18

58 See U.S. ConST. art. II, cl. 2 (President "shall have Power, by and with the Advice and Consent of the Senate, to make Treaties, provided two thirds of the Senators present concur; and he shall nominate, and by and with the Advice and Consent of the Senate").

59 Multilateral Treaties Deposited with the Secretary General: Status as AT 31 DEC. 1992, at 132, U.N. Doc. ST/LEG/SER.E/11 (1993).

60 Multilateral Treaties Deposited with the Secretary General: Status as at 31 DEC. 1994, at 185, U.N. Doc. ST/LEG/SER.E/13 (1995).

61 Adopted Dec. 10, 1984, G.A. Res. 39/46, 39 UN GAOR, Supp. (No. 1), U.N. Doc. A/39/51, at 197 (1984) (entered into force June 26, 1987)

62 See, e.g., David Sloss, The Domestication of International Human Rights: Non-Self-Executing Declarations and Human Rights Treaties, 24 YALE J. INT'L L. 129 (1999) [hereinafter Sloss, Domestication]; Michael J. Glennon, The Constitutional Power of the United States Senate to Condition Its Consent to Treaties, 67 CHI.-Kent L. REV. 533 (1991); Jordan J. Paust, Self-Executing Treaties, 82 AM. J. INT'L L. 760 (1988).

63 See Sloss, Domestication at 153 ("The Bush Administration presented different explanations at different times, shifting back and forth between the Foster concept and the "private cause of action concept."').

64 See, e.g., Igartua de la Rosa v. United States, 32 F.3d 8, 10 n.1 (1st Cir. 1994) (declaring rights provisions in ICCPR non-self-executing); Ralk v. Lincoln Country, Georgia, 81 F. Supp. 2d 1372 (S.D. Ga. 2000) (same); Heinrich v. Sweet, 49 F. Supp. 2d 27, 44 (D. Mass. 1999) (same); White v. Paulsen, 997 F. Supp. 1380 (E.D. Wash. 1998) (same); In the Matter of the Extradition of Cheung, 968 F. Supp. 791, 803 n.17 (D. Conn. 1997) (same). 
the states or the federal government. This is particularly striking in the case of state courts holding that the ICCPR does not bind the states because the Supremacy Clause expressly requires that state court judges are "bound" to apply this "supreme Law." ${ }^{55}$ For example, the Nevada Supreme Court in Domingues v. Nevada held that the ICCPR's prohibition of juvenile executions did not bind the State of Nevada because the Senate had declared that provision of the treaty to be non-self-executing. ${ }^{66}$ Although a treaty may allow states to exercise a certain margin of appreciation in how they go about complying with their treaty obligations, ${ }^{67}$ it is a wholly different matter to say that a court cannot give the treaty's obligations any legal effect whatsoever without implementing legislation. To implement this latter claim effectively voids the legal nature of the treaty in violation of international law $^{68}$ and the U.S. Constitution. ${ }^{69}$

In the situation of the Non-Self-Execution Doctrine's application to the federal government, federal courts have held some treaties to be selfexecuting. $^{70}$ Even those constitutional scholars who have set forth the extremist argument that most treaties should be presumed to require implementing legislation have not dared venture to argue that all treaties have no legally binding authority under the U.S. constitutional scheme. ${ }^{71}$ After all, the Supremacy Clause clearly eliminates that possibility by making treaties part of the supreme law of the land.

The controversy over the constitutionality of such non-self-execution declarations already appears to have adversely affected Supreme Court jurisprudence. In Lawrence v. Texas, ${ }^{72}$ the Supreme Court appeared to want to avoid the controversy by not citing the UN Human Rights Committee's decision in Toonen $v$. Australia, ${ }^{73}$ which held that the right to privacy guaranteed by the ICCPR extended to the protection of homosexual conduct. By not citing Toonen - a case particularly on point-the Court appeared to want to avoid addressing the issue of whether the ICCPR is indeed non-

65 U.S. CONST. art. VI.

66 Domingues v. State, 114 Nev. 783 (Nev. 1998).

67 See, e.g., Handyside v. United Kingdom, 24 Eur. Ct. H.R. (ser. A) (1976) (allowing state-party to European Convention on Human Rights to exercise a margin of appreciation in protecting morals of children).

68 Vienna Convention, art. 27 ("A party may not invoke the provisions of its internal law as justification for its failure to perform a treaty.").

69 U.S. CONST. art. VI (treaties are part of the supreme law of the land).

70 See, e.g., United States v. Percheman, 32 U.S. (7 Pet.) 51 (1833) (holding that treaty earlier found to be non-self-executing in Foster $v$. Neilson was self-executing according to Spanish version).

71 See, e.g., John C. Yoo, Globalism and the Constitution: Treaties, Non-Self-Execution, and the Original Understanding, 99 COLUM. L. REV. 1955, 1962 (1999) ("original understanding does not definitively show that all treaties must be non-self-executing").

72539 U.S. 558 (2003).

73 Communication No. 488/1992, U.N. Hum. Rts. Ctte., U.N. Doc. CCPR/C/50/D/488 (1994) (right to privacy includes right to engage in homosexual conduct under ICCPR). 
self-executing as the President and Senate declared. However, whether the $I C C P R$ is self-executing or not is not relevant because the Texas antisodomy statute at issue in Lawrence did not implicate the separation of powers principle that undergirds the Non-Self-Execution Doctrine. The U.S. Supreme Court is not demanding action from any political branch of the federal government that would violate the separation of powers principle. The Supremacy Clause disposes the issue by explicitly requiring state courts to comply with the United States' treaty obligations.

Instead, the Court cited several European Court of Human Rights decisions that interpreted the European Convention of Human Rights' guarantee of the right to privacy to include the protection of homosexual conduct. ${ }^{74}$ In doing so, the Court effectively opted to employ a treaty to which the United States is not a party in construing our Constitution. This move unnecessarily strengthened the hand of those who see some judges as improperly using purportedly "foreign law" in construing the Constitution. ${ }^{75}$ This issue avoidance now has resulted with the Supreme Court accepting the non-self-execution declaration without any critical analysis. ${ }^{76}$

However, the constitutional controversy over such non-self-execution declarations and the Non-Self-Execution Doctrine itself can be circumvented by employing the ILC approach. Again, the solution to ensure that human rights guaranteed by international law are given effect is to construe the human rights provisions of the Constitution in conformity with this international law. For example, the human rights guaranteed by the first eight Amendments are self-executing. ${ }^{77}$ Indeed, the Supreme Court already has noted that the privileges and immunities guarantee of the Fourteenth Amendment include those guaranteed by treaty. ${ }^{78}$ Therefore, construing these constitutionally guaranteed human rights in conformity with the United States' human rights treaty obligations gives effect to this international human rights law. Even those human rights treaties that the United States has declared to be non-self-executing can be used as evidence of the United States' explicit acceptance of customary international law norms codified in such treaties. Such customary international law can be used to

74 See Lawrence v. Texas, 539 U.S. 558, 576 (citing Dudgeon v. United Kingdom, Modinos v. Cyprus, and Norris v. Ireland).

75 Supreme Court justices (whether supportive or non-supportive of the use of international law) also often refer to international law merely as "world opinion" or "foreign law" in an apparent attempt distance themselves from such a mandatory construction. See, e.g., Roper v. Simmons, 125 S. Ct. 1183, 1200 (2005) (Kennedy, J.,) (referring to international law as "world opinion"); id. at 1229 (Scalia. J., dissenting) (referring to international law as "foreign law").

76 Sosa, 542 U.S. at 734 ("[A]lthough the [ICCPR] does bind the United States as a matter of international law, the United States ratified the Covenant on the express understanding that it was not self-executing and so did not itself create obligations enforceable in the federal courts.") (dictum).

77 See City of Boerne v. Flores, 521 U.S. 507, 524 ("first eight Amendments to the Constitution set forth self executing prohibitions on governmental action").

78 Slaughter-House Cases, 83 U.S. (16 Wall.) 36, 79 (1873). 
construe the human rights guarantees in the Constitution because the Constitution as a treaty must be construed in conformity with customary international law according to the conventional law of nations. ${ }^{79}$

Furthermore, in cases where the Constitution's language is silent on other human rights (such as privacy and the right to travel), the Ninth Amendment ${ }^{80}$ can be construed in conformity with international human rights law that does explicitly guarantee such rights. ${ }^{81}$ Such an international legal construction is essential for recognizing human rights that are not explicitly mentioned in the Constitution and, as a result, are often not protected. $^{82}$ Accordingly, one can make an end-run around the issue of nonself-execution by using the ILC approach because the issue of requiring implementing legislation is made moot. ${ }^{83}$

\section{CONCLUSION}

Over the last two hundred years, the U.S. Supreme Court has fabricated two weapons whose use by the United States often makes it an outlaw in the international community: the Last-in-Time Rule and the Non-SelfExecution Doctrine. The latter weapon allows double-dealing by, on the

79 See Vienna Convention, art. 31(3)(c) (treaty must be interpreted in light of "any relevant rules of international law applicable in the relations between the parties"); Vienna Convention-SIO, art. 31(3)(c) (treaty between intergovernmental organization and state must be interpreted in light of "any relevant rules of international law applicable in the relations between the parties"); Geofroy v. Riggs, 133 U.S. 258, 271 (1890) (meaning of treaty language "to be taken in their ordinary meaning, as understood in the public law of nations"); Legal Consequences for States of the Continued Presence of South Africa in Namibia (South West Africa) notwithstanding Security Council Resolution 276 (1970), Advisory Opinion, 1971 I.C.J. 16, 31 (1971) ("an international instrument has to be interpreted and applied within the framework of the [international juridical] system prevailing at the time of the interpretation"); Interpretation of the American Declaration of the Rights and Duties of Man within the Framework of Article 64 of the American Convention on Human Rights, Advisory Opinion OC-10/89, Inter-Am. Ct. H.R. Ser. A, No. 10, at II 37 (1989) (same); Coard v. United States, Inter-Am. C.H.R. Report No. 109/99, OEA/Ser.L/V/11.06, doc 3 rev (1999), available at http://www.cidh.oas.org/annualrep/99eng/ Merits/UnitedStates10.951.htm (last visited Feb. 15, 2003) (same).

80 U.S. CONST. amend. IX ("The enumeration in the Constitution, of certain rights, shall not be construed to deny or disparage others retained by the people"). Ninth Amendment rights are enforceable in federal and state courts. See, e.g., Griswold v. Connecticut, 381 U.S. 479 (1965) (right to privacy enforceable in federal court); In re Sherol, 581 P.2d 884 (Okla. 1978) ( $9^{\text {th }}$ Amendment right to respect for family integrity enforceable in state court); Voichahoske v. City of Grand Island, 194 Neb. 175 (1975) ( $9^{\text {th }}$ Amendment right to marry enforceable in state court).

81 See, e.g., ICCPR, arts. 12 (right to privacy) and 13 (right to travel); see also MARTIN, Challenging Human Rights Violations 64-65; Jordan J. Paust, Human Rights and the Ninth Amendment: A New Form of Guarantee, 60 CoRnELL L. REV. 231 (1975).

82 See, e.g., Bowers v. Hardwick, 478 U.S. 186 (1986) (no privacy right to engage in homosexual conduct under the $4^{\text {th }}$ and $5^{\text {th }}$ Amendments), rev' $d$ in Lawrence v. Texas, 539 U.S. 558.

83 In civil cases involving federal defendants accused of constitutional violations as construed by the United States' international legal obligations per the ILC Rule, plaintiffs can use a Bivens/Bolling action for seeking damages and/or injunctive relief. See Bivens v. Six Unknown Named Agents, 402 U.S. 388 (1971) (recognizing private cause of action for $4^{\text {th }}$ Amendment violations); Bolling v. Sharpe, 347 U.S. 497 (1954) (recognizing private right to injunctive relief for $5^{\text {th }}$ Amendment violations). 
one hand, agreeing to be bound by a treaty and, on the other hand, reserving the right to not give the treaty any effect. The former allows the United States to blatantly cast aside its treaty law obligations without any reason whenever it wishes to do so. Both weapons facilitate assaults on the rule of law. However, the implementation of ILC ensures that constitutional interpretation remains faithful to the rule of international law and rejects the hegemonic hypocrisy of an armed thug that struts of the international community demanding its neighbors to obey the law while it violates it.

Although the U.S. Supreme Court already repeatedly has used international law as persuasive authority in construing different constitutional provisions, ${ }^{84}$ the Court recently has attempted to distance itself from a constitutional construction with international law that is mandatory. For example, in Roper v. Simmons, ${ }^{85}$ the Court stated that the international law that it used to construe the Eighth Amendment was not controlling. Such international law merely provided a "respected and significant confirmation" of the Court's conclusions. ${ }^{86}$ The Court's decision in Roper is particularly troubling because unlike Lawrence in which the Court relied only upon case law that can properly be used only as confirmation of the Court's constitutional (i.e., treaty) interpretation according to the conventional law of nations, ${ }^{87}$ the Roper Court used an explicit prohibition in a treaty to which the United States is a party-but only as confirmation of the correctness of its constitutional interpretation. The Roper Court should have used the

84 See, e.g., Lawrence, 539 U.S. at 573 (citing European Court of Human Rights case law); Grutter v. Bollinger, 539 U.S. 306, 342 (2003) (Ginsburg, J., concurring) (citing International Convention on the Elimination of All Forms of Racial Discrimination for construing $14^{\text {th }}$ Amendment's equal protection guarantee in support of affirmative action program); Atkins v. Virginia, 536 U.S. 304, 16 n.21 (2002) (citing amicus brief from European Union in McCarver v. North Carolina); Thompson v. Oklahoma, 487 U.S. 815, n.34 (1988) (citing ICCPR for construing $8^{\text {th }}$ Amendment's prohibition of cruel and unusual punishment in prohibiting execution of persons under the age of 16 committing capital crimes); Kennedy v. Mendoza-Martinez, 372 U.S. 144, 161 n.16 (1963) (citing Universal Declaration of Human Rights for construing $5^{\text {th }}$ and $6^{\text {th }}$ Amendment in citizenship revocation case).

85125 S. Ct. 1183, (2005) (construing $8^{\text {th }}$ Amendment in conformity with international law).

86 Id. at 1200.

87 Although international courts cite their own precedents, decisions made by international courts, strictly speaking, only bind the parties to the case. See, e.g., Statute of the International Court of Justice, June 26, 1945, art. 59, 59 Stat. 1055, T.S. 993 ("The decision of the [ICJ] has no binding force except between the parties and in respect of that particular case.") [hereinafter ICJ Statute]. Case law is only used as a subsidiary means of interpreting treaties. ICJ Statute, art. 38 (1)(d) (ICJ shall apply "subject to the provisions of Article 59, judicial decisions . . . as subsidiary means for the determination of rules of law").

However, the EU Charter of Fundamental Rights recently has recognized the binding character of case law of the European Court of Justice and European Court of Human Rights upon all EU member states. See Charter of Fundamental Rights of the European Union, preamble, II 5, 2000 O.J. (C 364) 1 (entered into force Dec. 7, 2000) ("This Charter reaffirms . . . the rights as they result, in particular, from . . . the case-law of the Court of Justice of the European Communities and of the European Court of Human Rights."). 
ICCPR's explicit prohibition of juvenile executions ${ }^{88}$ as a mandatory legal authority for construing the Eighth Amendment. In attempting to take the middle road between a mandatory international legal construction and a construction that disregards international law altogether, by characterizing the use of such international law as only "persuasive," the Supreme Court unfortunately has driven itself into a conceptual dead end that compromises the integrity and coherence of the Court's constitutional jurisprudence. Only by recognizing that the Constitution is a treaty that must be construed in conformity with the United States' international legal obligations can the Court firmly justify its reliance upon international law. And, most importantly, only can such a recognition ensure that those human rights protections guaranteed by international law are guaranteed also by the Constitution. 